\title{
A MODEL FOR PSYCHIATRIC NURSING ACCOMPANIMENT OF THE PATIENT WITH MENTAL DISCOMFORT: PART III
}

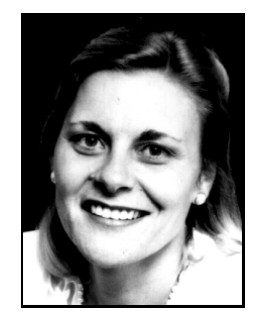

Prof. M Greeff

DCur; School of Nursing Science; PU for CHE

\section{ABSTRACT}

The research process did not proceed in the traditional step-by-step manner. A theory generating approach was followed by way of exploration and description. The first three levels: factor isolating, factor relating and situation relating theories, were generated. A conceptual framework for psychiatric nursing accompaniment of the patient with mental discomfort was formulated on the basis of concept identification and classification. The concepts mental discomfort, lifestyle functioning and psychiatric nursing accompaniment were identified and subjected to concept analysis. A systematic, logical and consistent approach led to the conceptualisation of the model for psychiatric nursing accompaniment of the patient with mental discomfort.

This addressed the initial question according to which the psychiatric nursing specialist could direct her interaction, and also cleared up the confusion surrounding the concept of accompaniment. The quest for wholeness was set as the final goal of the accompaniment events, and lifestyle functioning was established as a unit for assessment and diagnosis.

Hypotheses for validation of the model were formulated for follow-up research. The conceptualised model for psychiatric nursing accompaniment of the patient with mental discomfort was followed by a literature survey of models and theories for nursing and related disciplines and critically judged according to their main themes, application possibilities and limitations. The model for psychiatric nursing accompaniment of the patient with mental discomfort was evaluated on the basis of predetermined criteria. The shortcomings and conclusions were indicated and recommendations were made according to the operational possibilities of the research.

\section{OPSOMMING}

Die navorsingsproses het nie volgens die tradisionele, stapsgewyse metode plaasgevind nie. ' $n$ Teoriegenererende uitgangspunt is gebruik deur die toepassing van ondersoek en beskrywing. Die eerste drie vlakke: faktor-isolering, faktor-verwantskap en situasionele verwante teorieë is gegenereer. 'n Konseptuele raamwerk vir psigiatriese verpleegkundige begeleiding van die pasiënt met geestesongemak is geformuleer op grond van konsep-identifikasie en -klassifikasie. Die konsepte geestesongemak, lewenstylfunksionering en psigiatriese begeleiding is geïdentifiseer en onderwerp aan konsep-analise. 'n Sistematiese, logiese en konsekwente aanslag het gelei tot die konseptualisering van die model vir psigiatriese verpleegkundige begeleiding van die pasiënt met geestesongemak.

Dit het die oorspronklike vraag aangespreek na aanleiding waarvan die psigiatriese verpleegspesialis haar 
interaksie kan rig en het ook die verwarring rondom die konsep "begeleiding" opgeklaar. Die strewe na heelheid was die hoofdoel van die begeleiding en lewenstylfunksionering is daargestel as eenheid vir beraming en diagnosering.

Hipoteses vir validasie van die model is geformuleer vir verdere navorsing. Die konsep-model vir psigiatriese verpleegkundige begeleiding van die pasiënt met geestesongemak is gevolg deur 'n literatuurstudie van modelle en teorieë vir verpleegkunde en aanverwante dissiplines en is krities beoordeel volgens die hooftemas, toepassingsmoontlikhede en beperkinge. Die model vir psigiatriese verpleegkundige begeleiding van die pasiënt met geestesongemak is geëvalueer op grond van die voorafbepaalde kriteria. Die tekortkominge en gevolgtrekkings is aangedui en voorstelle is gemaak na aanleiding van die toepassingsmoontlikhede van die navorsing.

\section{INTRODUCTION}

The preceding articles on the research, namely: "A model for psychiatric nursing accompaniment of the patient with mental discomfort": PART I, Curationis, Vol. 16, No. 1 (April 1993), gave a complete explanation of the research design and methods of this theory generating approach. The second article: “"n Model vir psigiatriese verpleegkundige begeleiding van die pasiënt met geestesongemak": DEEL II, Curationis, Vol. 16, No. 3 (October 1993), explained the analysis of the concept mental discomfort. For the purpose of this article the final visual model for psychiatric nurs- ing accompaniment of the patient with mental discomfort (see figure 1) as well as an overview of the already formulated aspects applicable to the model will be portrayed. A full description of the conceptualised model for psychiatric nursing accompaniment of the patient with mental discomfort will then follow as depicted in Greeff (1991).

\section{THE FINAL VISUAL MODEL FOR PSY- CHIATRIC NURSING ACCOMPANI- MENT OF THE PATIENT WITH MEN- TAL DISCOMFORT}

The final visual model was constructed after dia

\section{A MODEL FOR PSYCHIATRIC NURSING ACCOMPANIMENT OF THE PATIENT WITH MENTAL DISCOMFORT}

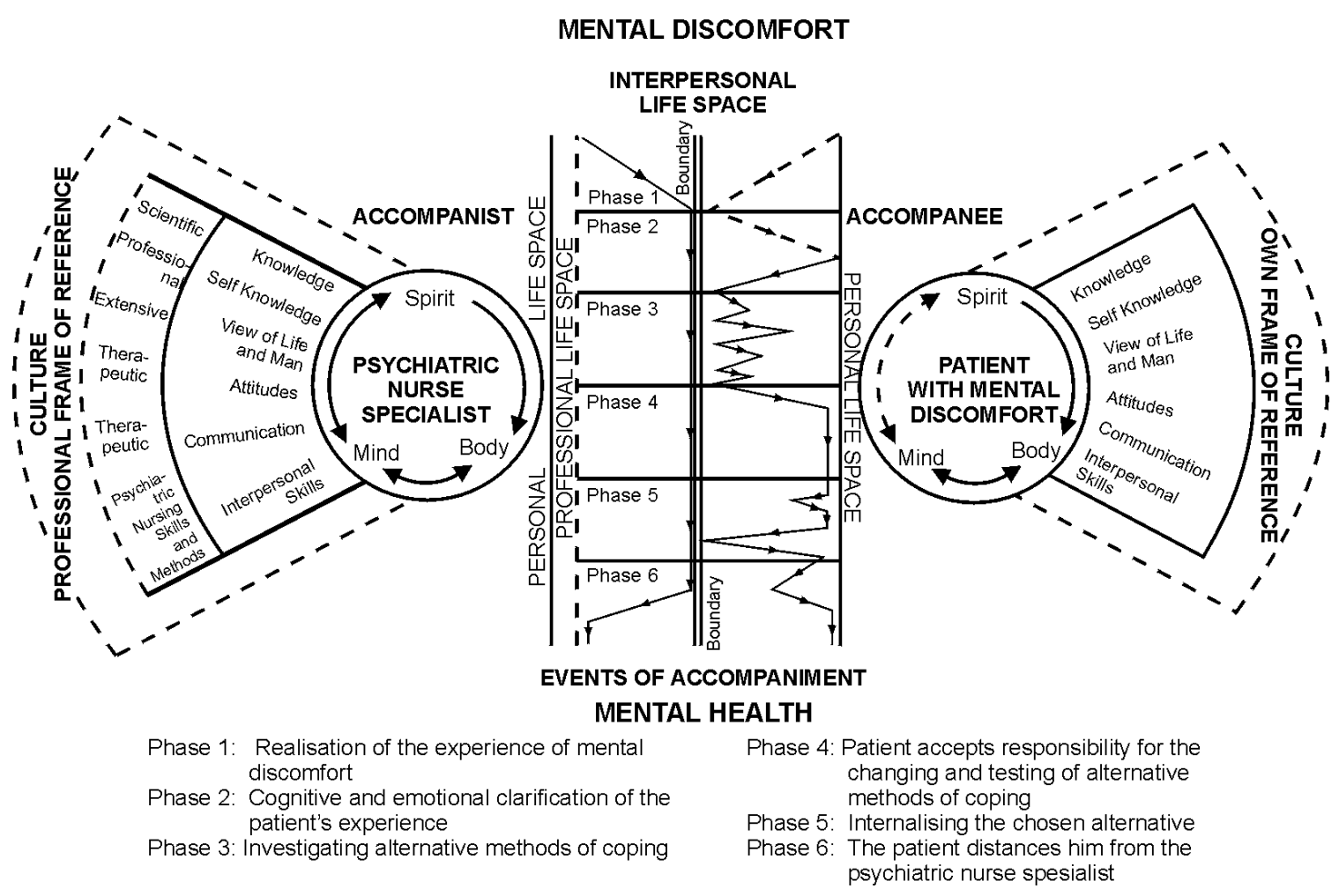


logue with experts, by ensuring the incorporation of changes in the reasoning processes of both the conceptual framework as well as the visual model. Figure 1 reflects the final constructed visual model on the basis of which the rest of the model conceptualisation will be explained and discussed. This final visual model serves as context for the description of the model for psychiatric nursing accompaniment of the patient with mental discomfort.

\section{AN OVERVIEW OF ALREADY FORMU- LATED ASPECTS APPLICABLE TO THE MODEL FOR PSYCHIATRIC NURSING ACCOMPANIMENT OF THE PATIENT WITH MENTAL DISCOMFORT}

Before continuing with the detailed description of the model for psychiatric nursing accompaniment of the patient with mental discomfort, it is necessary to briefly mention the aspects applicable to the model for psychiatric nursing accompaniment of the patient with mental discomfort, in order to be consistent and systematic.

Main concepts applicable to the model for psychiatric nursing accompaniment of the patient with mental discomfort

- Research parameters: Individuals with mental discomfort

- Purpose of psychiatric nursing accompaniment (frame of reference): Promotion of mental health as integral part of health

- Desired patient outcome (end result): Health (wholeness in body, mind and spirit)

- Unit of assessment and diagnosis: Lifestyle functioning

- Nature of the environment: Internal and external environment in continuous interaction

- Supporter: Psychiatric nursing specialist

- Methodology: Psychiatric nursing accompaniment
Conceptual definitions of the three analysed concepts of the model for psychiatric nursing accompaniment of the patient with mental discomfort

Three concepts were identified for concept analysis namely: mental discomfort, lifestyle functioning and psychiatric nursing accompaniment. After the investigation of dictionary and subject specific definitions, construction of model and marginal cases, and formulation of criteria for each concept, the three concepts were reformulated and conceptually defined.

\section{Mental discomfort}

Mental discomfort is the subjective, reality-orientated experience of an individual feeling internal discomfort (psychological and/or spiritual). The individual's own unique perception and cognisance of the pressure and demands that developed over a long period, for no specific reason, from his personal and/or work life, contribute to his/her discomfort. This internal discomfort is not necessarily observable by others. The experience leads to a gradual feeling of losing control (cognitive and emotional) in his life because of a temporary fading of coping mechanisms and problem-solving methods which would otherwise be effective. The individual's level of lifestyle functioning at work and on a social and personal level is maintained with difficulty and he/she experiences it as a change in his/her ability to handle situations.

\section{Lifestyle functioning}

Lifestyle functioning is the observable, unique manifestation of an individual's behaviour, emotions and thoughts because of the complex, interdependent, dynamic process of interaction between his internal environment (body, mind and spirit) and the external environment in his continued quest for wholeness. The manifestation occurs in the specific individual's daily functioning in a consequent and identifiable manner. The subjective process of formation already starts at birth and is sanctioned 
within a specific community's values and norms. The individual could periodically experience an enriching or problematic lifestyle functioning during the process of his/her daily functioning, but could go to the extreme and present a disorganised lifestyle.

\section{Psychiatric nursing accompaniment}

Psychiatric nursing accompaniment is a psychiatric nursing method aimed at the management of the patient with mental discomfort. It is a mental health promotive (preventative and enriching) and problem-solving, cognitive and emotional way of interaction, that develops between a patient becoming aware of his experience of mental discomfort and a psychiatric nursing specialist. It is aimed at facilitating the upliftment of a problematic lifestyle because of the experience of mental discomfort.

The patient willingly enters into a temporary, shortterm interaction and maintains full control, freedom of choice and responsibility for his own behaviour. The psychiatric nursing specialist at no stage violates the patient's personal boundaries.

The aim is to guide the patient to a cognitive and emotional clarification of his mental discomfort, investigate alternative coping mechanisms, take responsibility for change and choices, as well as internalise the chosen alternative. The patient then distances himself from the psychiatric nursing specialist, and the process of psychiatric nursing accompaniment comes to an end.

\section{SUMMARY}

Before the rest of the model for psychiatric nursing accompaniment is conceptualised and described, it is necessary to once again bring the following to the reader's attention. Psychiatric nursing accompaniment only applies to interaction with the patient experiencing mental discomfort. It does not apply to the patient with mental illness or who presents a disorganised lifestyle. With the men- tally ill patient, long term support and therapy would more likely manifest as possible ways of interaction.

\section{DESCRIPTION OF THE CONCEP- TUALISED MODEL FOR PSYCHIATRIC NURSING ACCOMPANIMENT OF THE PATIENT WITH MENTAL DISCOM- FORT}

The description of the conceptualised model for psychiatric nursing accompaniment of the patient with mental discomfort implies a description of the structure as well as the process of the model. An explanation of these aspects follows.

\section{THE STRUCTURE OF THE MODEL FOR PSYCHIATRIC NURSING ACCOMPANI- MENT OF THE PATIENT WITH MEN- TAL DISCOMFORT}

The structure of the model for psychiatric nursing accompaniment of the patient with mental discomfort is determined by looking at the most central relation of the model. The investigation of the structure of the model for psychiatric nursing accompaniment reveals the following:

The model for psychiatric nursing accompaniment does not contain a clear, single structure, but represents a combination of possibilities.

The most central relationship derived from the model is:

Psychiatric nursing accompaniment facilitates the upliftment of the experience of mental discomfort in the patient and therefore improves his mental health.

Structures identifiable are: mental discomfort, lifestyle functioning and psychiatric nursing accompaniment.

\section{Mental discomfort}

The concept mental discomfort forms an integral 
part of mental health, which in turn is an integral part of health. Health implies wholeness of body, mind and spirit. There are therefore various overlapping interactive dimensions and aspects, which can not be hierarchically arranged.

Health contains the dimensions: body, mind and spirit, where each dimension has its own characteristics, is in constant interaction with each other and does not stand separately, but forms a whole.

\section{Lifestyle functioning}

Lifestyle functioning as unit of assessment and diagnosis is presented as a continuum concept which can move from enriching to disorganised. Mental discomfort is found on this continuum as one of the levels of lifestyle functioning. Lifestyle functioning can therefore imply various levels.

\section{Psychiatric nursing accompaniment}

Although psychiatric nursing accompaniment has a beginning and ending phase, with health as goal, the concept health is a relatively abstract and theoretical concept that can not be measured empirically. The process of psychiatric nursing accompaniment is more circular, since psychiatric nursing accompaniment is aimed at uplifting the experience of mental discomfort in the patient and to facilitate mental health. An individual could however experience a need for psychiatric nursing accompaniment because of pressure and demands from his environment.

Since the last mentioned substructure reflects the central process of the model for psychiatric nursing accompaniment of the patient with mental discomfort, it seems as if the structure of the model is circular in nature.

THE PROCESS OF THE MODEL FOR PSYCHIATRIC NURSING ACCOMPANIMENT OF THE PATIENT WITH MENTAL DISCOMFORT

The description of the process of the model for psy- chiatric nursing accompaniment of the patient with mental discomfort follows:

\section{Goal content specified as the goal for activ- ity by the psychiatric nursing specialist dur- ing psychiatric nursing accompaniment}

Psychiatric nursing accompaniment by the psychiatric nursing specialist is aimed at facilitating the patient's quest for health (wholeness in body, mind and spirit), by changing the problematic lifestyle functioning of the patient experiencing mental discomfort (psychological and/or spiritual) to an improved mental health (psychological and/or spiritual) functioning.

\section{Prerequisites for psychiatric nursing accom- paniment}

Before accompaniment can meaningfully commence, certain prerequisites for the activation and course of the process are necessary.

\section{Regarding the patient qualifying for accom- paniment and who therefore activates it:}

The experience of a feeling of internal mental discomfort (psychological and/or spiritual); cognitive and emotional cloudedness in the patient; no disorganisation present in the patient's lifestyle functioning; an indication of a problematic lifestyle functioning; a cognitive ability to converse intellectually with the accompanist, irrespective of the experience of mental discomfort by the patient; voluntary entry into the process of accompaniment by the patient; permission to activate accompaniment granted by the patient to the accompanist; belief in the psychiatric nursing specialist's professional capabilities and personal characteristics.

\section{Regarding the accompanist:}

Love and respect for fellow human beings as underlying to the process of accompaniment; the need for mental health promotive action by the psychi 
atric nursing specialist; the willingness of the psychiatric nursing specialist to invest time and energy in the process of accompaniment; the ability of the psychiatric nursing specialist to allow the patient to maintain control, allowing him freedom of choice, responsibility, as well as maintaining independence during accompaniment; a positive outlook on life, as well as a sense of futurity in the psychiatric nursing specialist; acceptance of the patient as a responsible and dignified individual.

\section{Regarding the process of accompaniment:}

An atmosphere of equality and respect for each other; the availability of a psychiatric nursing specialist as accompanist, with more cognitive and emotional clarity than the patient with mental discomfort; an interpersonal process with the possibility of mutual interaction; the goal of facilitating the upliftment of the experience of mental discomfort; a trusting basis with the possibility of a deepened trusting relationship; mutual maintenance of control, freedom of choice, responsibility and independence from both parties involved in accompaniment.

\section{The course of accompaniment}

The process of psychiatric nursing accompaniment of the patient with mental discomfort is a dynamic, temporary and short-term facilitating interaction between the psychiatric nursing specialist as accompanist and the patient with mental discomfort as the accompanee. It is a mental health promotive interaction and supports the patient to extend his ability for daily activity and experience, to lead a fuller, more satisfying life. It is therefore aimed at self-development, growth and a high level of health.

The psychiatric nursing specialist maintains her own, as well as a professional, human and life perspective, as well as ethical and moral values at all times, but never at the cost of the patient. She never forces her own set of values on the patient.

The process moves through various phases, each with its own occurrences during that specific phase, and it moves from an experience of mental discomfort (problematic lifestyle functioning) to mental health (enriching lifestyle functioning).

Subsequently a layout of the accompaniment phases:

\section{Awareness of the experience of mental dis- comfort:}

The patient gradually becomes aware of an experience of internal discomfort, namely mental discomfort, which develops from the pressure and demands of his personal and/or working life, but with no identifiable origin. He starts feeling that there is a change in his ability to cope with situations and that coping mechanisms and problem-solving methods normally applied, temporarily fade. It becomes increasingly difficult to maintain his level of lifestyle functioning. The inner experience and feeling of loss of control is not necessarily observable, and the patient feels more and more isolated. This experience activates the patient to willingly enter into interaction with the psychiatric nursing specialist. The psychiatric nursing specialist moves from a position of "availability" to a position of "presence" for the patient by making herself available for the facilitation of upliftment of mental discomfort. The psychiatric nursing specialist - with her delicate attunement towards her fellow human being - enters into the interaction with openness to get a sense of the experienced emotions and to break down the barriers between her and her fellow human being, but at all times respects the body boundaries of the patient and never oversteps these boundaries. An extent of control of the boundaries develops, but not of respect and love. Respect and love towards fellow human beings is therefore an important core element of the process from the com 
mencement of interaction.

\section{Cognitive and emotional clarification of the patient's experience:}

Should the patient become aware of his mental discomfort during the awareness phase, he must decide if he wants to permit the continuation of accompaniment. The psychiatric nursing specialist only moves towards the patient's body boundary but never violates the patient's privacy. Since the psychiatric nursing specialist utilises her professional life space, the privacy of the psychiatric nursing specialist is protected. Although the psychiatric nursing specialist is the expert in this process, it is the patient that indicates the direction of interaction from his personal needs and who maintains control, freedom of choice and responsibility for his own action.

Expectations regarding the process of psychiatric nursing accompaniment are clarified to ensure that both the patient and the psychiatric nursing specialist strive towards the same goals. From the beginning of the process the psychiatric nursing specialist activates control, freedom of choice and responsibility in the patient, since it forms the foundation of interaction. The patient can experience a partial loss regarding one of the three aspects, but the psychiatric nursing specialist supports him in realising that it occurred because of his mental discomfort.

In this phase the patient experiences a cognitive and emotional cloudedness because of the experience of mental discomfort. It becomes increasingly difficult for the patient to maintain his current level of lifestyle functioning. Entering into accompaniment could result in a temporary increase in the patient's interdependency of the psychiatric nursing specialist. The psychiatric nursing specialist must reformulate this as quickly as possible, to a more balanced interdependence.
The accompaniment interaction where the psychiatric nursing specialist pays attention and listens, provides the patient with the opportunity to ventilate re the pressure and demands of his personal and/or working life. The psychiatric nursing specialist follows in a cognitive-emotional interpreting fashion and enables the patient to identify his problem through cognitive and emotional clarification of his experience. The cloudedness is cleared and the patient acquires perspective of his situation. The patient starts feeling in control of his situation.

\section{Investigation of alternative methods:}

The fact that the psychiatric nursing specialist is the more knowledgeable and experienced person during accompaniment and possesses cognitive and emotional clarity, enables her to provide the patient with a variety of coping mechanisms and problem-solving methods. It is important for the patient to identify and reconfirm the coping mechanisms and problem-solving methods that has worked so far. In the investigation of alternatives the psychiatric nursing specialist initially lets the patient search for alternative coping mechanisms in his present situation. She is there for him while he investigates. At this stage she can introduce a few alternatives to the patient, but should not lapse into the process of giving advise.

The challenge to the psychiatric nursing specialist is to provide just enough support required by the patient to continue, and in doing so provides the patient with an opportunity for self-activity. There is therefore an interchange in direct and indirect guidance from the psychiatric nursing specialist.

\section{Patient accepts responsibility for change and tests alternative coping mechanisms:}

The patient is made aware of his own contribution to his experience of mental discomfort, and the psychiatric nursing specialist tries to get the patient to accept responsibility for changing coping 
mechanisms. The sense of responsibility of the patient is increased by his feeling of control. The patient is therefore called upon to find purpose and accept responsibility for self-action. The patient acquires freedom in his search for coherence. He tries to identify the relationship between situations and make the right decision regarding the alternative he is willing to test. During this phase the psychiatric nursing specialist provides the patient with the opportunity to exercise these choices in a safe atmosphere of trust and respect. The patient periodically discards the process of accompaniment to discover and to endeavour to make the psychiatric nursing specialist redundant. Should the patient feel unsure during this exercise he can always return to the process of accompaniment since the psychiatric nursing specialist is there and he knows from the trusting relationship that he is allowed to return. The patient is lead to the mobilisation of personal and environmental sources for effective coping with mental discomfort. The psychiatric nursing specialist can lead by example, act as role model or provide an exercising opportunity through role-play.

The patient is on his way, but the psychiatric nursing specialist accompanies him, observes how he goes and tells him what she sees. The patient is therefore active in exercising alternative coping mechanisms. The psychiatric nursing specialist actively participates, but does not accept responsibility for the patient.

\section{Internalisation of the chosen alternative:}

Since the psychiatric nursing specialist provides the patient with the opportunity to work through the various alternative coping mechanisms, to investigate and to exercise, it becomes possible for the patient to decide what he can make his own and what is alien to him. The recurring application of the chosen alternatives enables the patient to internalise the action and make it his own. During the application of alternatives the psychiatric nurs- ing specialist is a mirror image or reality resonator for the patient because of the existing position of trust. During the internalisation phase the psychiatric nursing specialist gradually moves from a position of "presence" to a position of "availability". The patient gradually takes control and responsibility and makes choices with more confidence.

\section{The patient distances himself from the psy- chiatric nursing specialist:}

Although the psychiatric nursing specialist moves from a position of "presence" to a position of "availability" and increasingly tries to make herself redundant, it is the patient who finally decides to establish the distance. This distancing is made possible by a strengthening in the patient's previous level of lifestyle functioning or even an increase in this level because of an enriching process that occurred during accompaniment. The patient has therefore developed a perspective of his situation. The patient chooses to continue alone, and the psychiatric nursing specialist makes herself available for future "presence". The process of psychiatric nursing accompaniment is terminated. The patient has thus changed his experience from mental discomfort to a lifestyle functioning testimonial of mental preparedness.

In conclusion it can be said that psychiatric nursing accompaniment uplifts the patient's experience of mental discomfort. He is lead to change his behaviour and can therefore experience an optimal level of health (wholeness in body, mind and spirit).

\section{The dynamics of the process of accompani- ment}

The dynamics of accompaniment takes place within the total framework of psychiatric nursing as interactional approach and is aimed at the improvement of the patient's mental health. The activating elements of dynamics in the accompanying process are amongst others the patient's level of lifestyle 
functioning, the psychiatric nursing specialist's quest for wholeness in herself and others, as well as the patient's environment.

The psychiatric nursing specialist is activated because of her love and respect for her fellow human beings, as well as the quest for wholeness in herself and others and to be available during times of problematic lifestyle functioning. Love and respect form the basis, as well as the climate for accompaniment. To date her availability was mainly because of her genuine personal frame of reference, and the person opposite her is her fellow human being in need of support. Should the other person become aware of his mental discomfort the process changes and he reaches out to her as a professional. The definition of the relationship now changes from a social relationship to a professional relationship and the person opposite her's status changes to that of patient.

The psychiatric nursing specialist now leaves her own frame of reference of personal and self knowledge, social attitudes and communication and interpersonal skills as social fellow human being, behind.

She enters as a professional into the interaction and her professional frame of reference forms the basis of her interaction with the patient experiencing mental discomfort. By utilising her professional frame of reference she applies her extensive theoretical knowledge, her professional self knowledge, her extensive life and human philosophy, therapeutical attitudes and communication, as well as her psychiatric nursing skills and methods. She is flexible and versatile, but consequent in stating her values and assumptions. Her personal value system gained from education and experience provides stability in her own demeanour, but is placed on the background regarding the patient. As professional guide she never forces her personal values on the patient. During this interaction it is the patient who must confirm his own value system, and the exposure to the value system of the psychiatric nursing specialist could only complicate the experience of mental discomfort, should the value systems be contradictory. The patient's value system is treated with respect, irrespective the discrepancy with that of the psychiatric nursing specialist.

The following subsequently comes under discussion in accompaniment, namely the interpersonal life space between the patient and the psychiatric nursing specialist. This interpersonal life space exists because of the personal boundaries of the patient as well as that of the psychiatric nursing specialist. To create a parallel in professional accompaniment, the psychiatric nursing specialist enters into this interaction with her professional boundaries and shifts her personal boundaries to the background. The boundaries between the patient's personal life space and the psychiatric nursing specialist's professional life space serve a specific goal during accompaniment. During a social or even therapeutic relationship this interpersonal life space boundary is overstepped with permission. It is this overstepping that distinguishes accompaniment from social or therapeutic interactions since the interpersonal life space boundary is never overstepped during psychiatric nursing accompaniment. It is this aspect that makes it possible for the patient to maintain control, freedom of choice and responsibility during the interaction with the psychiatric nursing specialist. The patient could grant the psychiatric nursing specialist permission to invade his privacy, but she must refrain from doing so. She concentrates on accentuating a feeling of control within the patient, as well as the contribution he made to his own existing mental discomfort.

The patient enters into accompaniment with a feeling of mental discomfort arising from the pressures and demands of his own personal and/or work life. He enters into accompaniment with specific expectations. The psychiatric nursing specialist also has specific expectations from her "presence" and a need to facilitate a quest for wholeness in herself 
and her patient. Both must place their expectations in perspective and let it run in parallel. The internal and external environment of the patient is of relevance. The psychiatric nursing specialists makes the patient aware of how much and to what extent he could have contributed to his own experience of mental discomfort and his ability to be free to determine his own behaviour. The experience of mental discomfort can create a temporary period of cognitive and emotional cloudedness in the patient since he cannot distinguish between the problem areas in his life. His coping mechanisms and problem-solving methods, which are normally effective, temporarily fade.

The psychiatric nursing specialist pays attention, listens and uses her internalised therapeutic attitudes and communication, as well as her psychiatric nursing skills to convince the patient to ventilate his experience of mental discomfort, to find meaning and to accept responsibility. The psychiatric nursing specialist never takes responsibility for the patient, but reflects genuine honesty, warmth and unconditional acceptance. She is at all times empathetic, concrete and congruent.

The patient feels safe due to the fact that the psychiatric nurse does not enter his personal life space and the trusting relationship increases. The psychiatric nursing specialist channels her supporting interactions during accompaniment to the patient's internal frame of reference (personal experiences regarding volition, emotion, thoughts and spirit from his internal environment) and not the external frame of reference (aspects involved with the patient from his external environment) as such. By ventilating aspects relating to the internal frame of reference, the patient is lead to cognitive and emotional clarifying, and subsequent clarity.

The fact that the psychiatric nursing specialist does not control or take over the freedom of choice and responsibility, enables the patient to maintain these aspects in himself, and even strengthen and extend them. It is because of her extended life and human philosophy and her professional frame of reference (formed by the exposure to the nursing profession with its specific values, norms and ethical principles), and not her personal frame of reference, that she can accompany the patient in his search for alternative coping mechanisms and problemsolving methods. The patient increasingly gains a feeling of control in his situation which up to now has been vague, and he declares himself willing to accept responsibility for investigating alternative coping mechanisms. The psychiatric nursing specialist provides the patient with the freedom of selfactivity and detaches herself in order not to measure her own effectiveness during these interactions by means of goal achievement.

The patient's experience of control, freedom of choice and acceptance of responsibility, to choose that alternative best suitable to him, provides him with the opportunity to internalise it as his own. The change brought forth in the patient is not in essence, but in his "essence of being". The patient's experience of mental discomfort is uplifted.

This experience of success and achievement makes it possible for the patient to part, without assistance, from the psychiatric nursing specialist after a short temporary period, since his mental discomfort is uplifted and he experiences a strength in himself that enables him to control his own lifestyle functioning, freedom of choice and take responsibility. The psychiatric nursing specialist accepts this distance and changes her position of "presence" to one of "availability". This availability of the psychiatric nursing specialist and the assurance that he can return to the process of accompaniment due to the existing trusting relationship, should he deem it necessary, strengthens the patient's experience of control, and it becomes increasingly possible for him to enrich and extend his lifestyle functioning. The process terminates and both return to a position of merely being fellow human beings. 


\section{CONCLUSION}

Should the psychiatric nursing specialist deem it necessary from her broader professional frame of reference, to redefine the relationship of accompanist to therapist, the prerequisites, the process as well as dynamics, undergo a total change. Permission to transgress into the patient's personal life space is now granted by him specifically and willingly and the psychiatric nursing specialist is allowed to transgress into this area. The personal life space of the patient could in the case of disorganised lifestyle functioning, be entered into on a non-willing basis. This transgression should at all times be professional and conducted with love and respect. The relationship is redefined and no longer falls within the context of psychiatric nursing accompaniment.

\section{BIBLIOGRAPHY}

GREEFF, M 1991: 'n Model vir psigiatriese verpleegkundige begeleiding van die pasiënt met geestesongemak. Auckland Park: Rand Afrikaans University, (Unpublished DCur (Psychiatric Nursing) thesis). 